Kai A. Konrad

\title{
Search Costs and Corporate Income Tax Competition
}

\author{
Max Planck Institute for Intellectual Property, \\ Competition and Tax Law and WZB
}

SP || $2010-11$

August 2010

Research Area Markets and Politics

Research Professorship \& Project "The Future of Fiscal Federalism"
Schwerpunkt

Märkte und Politik

Forschungsprofessur \& Projekt

"The Future of Fiscal Federalism" 
Kai A. Konrad, Search Costs and Corporate Income Tax

Competition, Discussion Paper SP II 2010 - 11,

Wissenschaftszentrum Berlin, 2010.

Wissenschaftszentrum Berlin für Sozialforschung gGmbH,

Reichpietschufer 50, 10785 Berlin, Germany, Tel. (030) 25491 - 0

Internet: www.wzb.eu 


\section{Search Costs and Corporate Income Tax Competition}

by Kai A. Konrad *

This paper studies corporate tax competition if it is costly to learn some of the elements that determine the effective tax burden. Search cost may, but need not, eliminate the tax competition pressure. The outcome depends on the boundaries of tax rate and tax base choices. Search cost can explain the empirically observed tax cuts cum base broadening.

Keywords: Costly search, tax competition, corporate taxation, monopoly pricing paradox

JEL classification: $H 70, H 87$

\section{ZUSAMMENFASSUNG}

\section{Suchkosten und Körperschaftssteuerwettbewerb}

Dieser Artikel untersucht den Körperschaftssteuerwettbewerb und insbesondere die Frage, ob es kostspielig ist, einige der Elemente in Erfahrung zu bringen, welche die effektive Steuerbelastung bestimmen. Suchkosten können, müssen aber nicht, den Druck des Steuerwettbewerbs aufheben. Das Resultat hängt von der Wahl der Steuerfreigrenzen und der Steuerbemessungsgrundlage ab. Suchkosten können die empirisch beobachteten Steuersenkungen, verbunden mit der Verbreiterung der Steuerbemessungsgrundlage, erklären.

* I thank Gerold Krause-Junk for making me interested in the role of tax base uncertainty and Aron Kiss for helpful suggestions. The usual caveat applies. 


\section{Introduction}

This paper introduces search cost in the theory of tax competition. It studies tax competition in search markets for foreign direct investors when the statutory tax rates are known but the effective tax base is not known, causing search costs to firms which are trying to find out countries' effective tax burdens prior to the investment location choice. ${ }^{1}$ Tax rates of different countries are typically well advertised and known or are accessible virtually without cost. It is much more difficult to learn the details of a country's tax rules, such as depreciation allowances, tax treatment of R\&D investment, treatment of capital gains, the integration of corporate taxation with other elements of the national tax system, a country's financial regulation and its rules regarding transfer pricing. A firm needs to know and to assess what these rules imply for tax optimization and for the resulting effective tax base for a given investment project. ${ }^{2}$ We find: as a variant of Diamond's (1971) monopoly pricing paradox ${ }^{3}$, the cost of learning countries' effective tax base has drastic consequences for the equilibrium outcome of tax competition. ${ }^{4}$ From a structural point of view, Harrington and Leahey (2007) is closest to our paper. They consider price competition between firms with unobserved delivery costs adding to sales prices. In our framework, countries compete for firms, and the (observed) tax rate and the (unobserved) tax base inter-

\footnotetext{
${ }^{1}$ For a recent survey of this large literature see Fuest, Huber and Mintz (2005). Search cost is not an issue that has been considered in this literature.

${ }^{2}$ As stated by the European Commission (2001, p.37): "[...] each Member State has its own sets of rules, in particular laws and conventions on financial accounting, rules for determining taxable profit, arrangements for collection and administration of tax and its own network of tax treaties. The need to comply with a multiplicity of different rules entails a considerable compliance cost and represents in itself a significant barrier to crossborder economic activity."

${ }^{3}$ Many variants of this Diamond paradox have been explored. Burdett and Judd (1983) analyzed a more general framework in which some firms may be informed about the prices in multiple firms, and showed that this may lead to an equilibrium with price dispersion, instead of monopoly pricing. More recent contributions are McAfee (1995), Baye and Morgan (2001), Arbatskaya (2007), Ireland (2007) who considers firms which sell through different outlets. Harrington (2001) considers competition in which price and quality are uncertain, with a high search cost for quality and a low search cost for the price.

${ }^{4}$ Unlike in Fuest (1995) who considers tax competition with redundancy of tax instruments, tax rate and tax base are not perfect substitutes here, as they differ by the aspect of search cost.
} 
act multiplicatively. We show that competition pressure may occur, despite the existence of search cost, depending on the size of the minimum feasible tax base. Our results show why competition can lead to a tax-cut-cumbase-broadening and explain this recent trend in the context of corporate taxation. It contributes a further explanation for the puzzle ${ }^{5}$ as to why corporate tax rates dropped in the last 25 years in OECD countries, whereas tax revenues from corporate taxation were sustained. ${ }^{6}$

\section{The formal framework}

We look for (weak) perfect Bayesian equilibrium in the following game with complete, but imperfect, information. There are $n$ ex-ante identical countries $j=1, \ldots, n$, and a set of investors $i$ with measure $1 .^{7}$ Each country chooses a statutory tax rate $t_{j} \in\left[\tau_{0}, \tau_{1}\right] \subseteq[0,1]$ and a tax base $b_{j} \in\left[\beta_{0}, \beta_{1}\right] \subseteq[0,1]$. The product of tax rate and tax base in a country is called the effective tax burden and denoted

$$
T_{j}=t_{j} b_{j}
$$

This $T_{j}$ is the fiscal price which investors have to pay for investing in country $j$. Each investor maximizes his net profit. He costlessly observes the statutory tax rates $t_{1}, \ldots, t_{n}$. The effective tax bases $b_{1}, \ldots, b_{n}$ are determined by a large number of details in the tax code such as depreciation rules or cost deduction allowances, the conduct of the tax administration, for instance, regarding transfer pricing issues or auditing habits, on specific characteristics of the investment project and its flexibility for tax optimization in the respective institutional framework. Evidently, $b_{j}$ should be understood as a metaphor for the less easily observable co-determinants of effective tax burden. To learn the actual $b_{j}$ of country $j$ the investor has a positive cost that is equal to $c>0$. To learn the tax bases of a set $K_{i} \subseteq\{1, \ldots, n\}$ of countries,

\footnotetext{
${ }^{5}$ See Sørensen (2007) and De Mooij and Nicodème (2008) for a balanced discussion.

${ }^{6}$ Devereux, Lockwood and Redoano (2008), for instance, report a drop in the average of the statutory rates of corporate taxation in the OECD countries from about 50 percent to under 35 percent in the period between the early Eighties and 2001. Devereux, Griffith and Klemm (2002) provide evidence for sustained tax revenue, despite these drops in rates.

${ }^{7}$ We deliberately choose a framework in which the different countries are as homogenous as possible along all dimensions ex ante, before choosing their tax burdens. Without search costs, this framework would yield a race to the bottom.
} 
the search cost is equal to $\left(\# K_{i}\right) c$, with $\# K_{i}$ the number of countries in $K_{i}$. For these countries $j \in K_{i}$, investor $i$ knows the effective tax burden $T_{j}$. For all $j \notin K_{i}, i$ must form a belief about $T_{j}$, described by a (possibly degenerate) probability distribution $F_{j}\left(T_{j}\right)$. Each investor invests one unit of capital (or does not invest at all). ${ }^{8}$ The investment turns into a gross profit of size $\pi\left(T_{j}\right)$. For this function, we assume that a higher tax rate reduces this gross profit. More precisely, $\pi(0)$ is the 'laissez-faire' profit, $\pi$ is a concave function of $T_{j}$ (i.e., $\pi^{\prime}<0$ and $\pi^{\prime \prime} \leq 0$ ) in the range $T_{j} \in[0,1]$ and zero for $T_{j}>1$. Intuitively, this is a short-hand notion for the idea that firms adjust their local business activity to taxation, that their activity will be negatively affected by a higher effective tax burden, and that firms have an exit option, which rules out an infinitely high tax burden. The gross profit $\pi$ is subject to the effective tax burden. Hence, the profit net of taxes and net of search costs for the investor $i$ who expends $\left(\# K_{i}\right) c$ units of search costs and invests in country $j$ is

$$
\left(1-t_{j} b_{j}\right) \pi\left(t_{j} b_{j}\right)-\left(\# K_{i}\right) c .
$$

Each government maximizes its tax revenues. ${ }^{9}$ If $\alpha_{j} \in(0,1)$ is the share of investors who invest in country $j$, then the tax revenue in country $j$ is

$$
\alpha_{j} t_{j} b_{j} \pi\left(t_{j} b_{j}\right)
$$

where $\alpha_{j}$ can, in general, be a function of $\left(\left(t_{1}, b_{1}\right), \ldots,\left(t_{n}, b_{n}\right)\right)$

We consider the following timing. Stage 1: the countries choose their statutory tax rates and their tax base definitions. Stage 2: the investors choose which information they will acquire about tax base definitions. Stage 3: investment choices take place.

It is useful to define the following benchmark: in the absence of tax competition, $\alpha_{j}$ is exogenous. This makes (3) a monotonic and concave function of the effective tax burden and has a unique maximum that is implicitly defined by the first-order condition

$$
T_{j} \pi^{\prime}\left(T_{j}\right)+\pi\left(T_{j}\right)=0 .
$$

\footnotetext{
${ }^{8}$ It is possible that the investor does not invest at all, but we will not consider this constraint explicitly in what follows, as it will not be binding under fairly general conditions.

${ }^{9}$ This is a standard assumption and may describe Leviathan government or a benevolent government that may want to extract revenue from non-resident investors on behalf of its population.
} 
We denote the solution to (4) as $T_{m}$ and call $T_{m}$ the effective monopoly tax.

Proposition 1 The following strategy profile and beliefs constitute a weak perfect Bayesian equilibrium: (i) For $\tau_{0} \beta_{1}<T_{m}$ : All countries choose $t_{j}=\tau_{0}$ and $b_{j}=\beta_{1}$. Investors believe that

$$
\begin{array}{ccc}
b_{j}=\beta_{1} & \text { for } & t_{j} \leq T_{m} / \beta_{1} \\
b_{j}=T_{m} / t_{j} & \text { for } & t_{j} \in\left(T_{m} / \beta_{1}, T_{m} / \beta_{0}\right] \\
b_{j}=\beta_{0} & \text { for } & t_{j}>T_{m} / \beta_{0}
\end{array}
$$

with probability 1 . They choose $K_{i}=\varnothing$ and invest in one of the countries with the (according to the beliefs) lowest effective tax burden. (ii) For $\tau_{0} \beta_{1} \geq$ $T_{m} \geq \tau_{0} \beta_{0}$ : All countries choose $t_{j} b_{j}$ with $t_{j} \in\left[\tau_{0}, \tau_{1}\right], b_{j} \in\left[\beta_{0}, \beta_{1}\right]$ such that $t_{j} b_{j}=T_{m}$. Investors $i$ believe that

$$
\begin{array}{ccc}
t_{j} b_{j}=T_{m} & \text { for } & t_{j} \in\left[T_{m} / \beta_{1}, T_{m} / \beta_{0}\right] \\
t_{j} b_{j}=t_{j} \beta_{0}>T_{m} & \text { for } & t_{j}>T_{m} / \beta_{0} .
\end{array}
$$

with probability 1 . They choose $K_{i}=\varnothing$ and invest in one of the countries with the lowest (believed) effective tax burden.

Proof. (i) In stage 3, each investor $i$ knows $b_{j}$ for $j \in K_{i}$ and has beliefs (5) about countries' $b_{j}$ for $j \notin K_{i}$. The investor chooses the country with the lowest $t_{j} b_{j}$ and randomizes between the different countries if there are several countries with the same effective tax burden. In stage 2, each investor $i$ observes $t_{1}, \ldots, t_{n}$ and chooses $K_{i}$. Given that the beliefs (5) are degenerate, the investor does not expect to learn anything from search. Hence, $K_{i}=$ $\varnothing$. Turning to stage 1 , for $t_{k}=\tau_{0}, b_{k}=\beta_{1}$ for all $k \neq j$, the country $j$ chooses $\left(t_{j}, b_{j}\right)$ to maximize (3). For $t_{j}>\tau_{0}$ and given the beliefs in (5), all investors expect the fiscal burden to be higher in this country than in the other countries. The country receives a tax revenue equal to zero in the continuation game. For $t_{j}=\tau_{0}$, its expected tax revenue is equal to

$$
\frac{1}{n}\left(\tau_{0} b_{j}\right) \pi\left(\tau_{0} b_{j}\right)
$$

and, as $\tau_{0} \beta_{1}<T_{m}$, this reaches its maximum for $b_{j}=\beta_{1}$. Note also that the beliefs are consistent along the equilibrium path. 
The reasoning for case (ii) is analogous for stages 2 and 3. In stage 1, countries anticipate that $K_{i}=\varnothing$. Given the simultaneous choices $t_{k} b_{k}=T_{m}$ for $k \neq j$, country $j$ anticipates that $j$ 's tax revenue is equal to

$$
\begin{array}{ccc}
\frac{1}{n} t_{j} b_{j} \pi\left(t_{j} b_{j}\right) & \text { if } & t_{j} \in\left[T_{m} / \beta_{1}, T_{m} / \beta_{0}\right] \\
0 & \text { if } & t_{j}>T_{m} / \beta_{0} .
\end{array}
$$

Accordingly, $j$ chooses $t_{j} \in\left[T_{m} / \beta_{1}, T_{m} / \beta_{0}\right]$ and a tax burden definition that maximizes $t_{j} b_{j} \pi\left(t_{j} b_{j}\right)$ for this $t_{j}$. This maximand is $b_{j}=T_{m} / t_{j}$. Note also that the beliefs are consistent along the equilibrium path.

Cases $(i)$ and $(i i)$ have in common that no search costs are incurred. Given the expectations of identical equilibrium effective tax base choices in the different countries, a costly search does not pay. In turn, because no firm searches, countries cannot attract additional investors by the choice of a low effective tax base. If the firms could commit to search actively, this would introduce competitive pressure, as a country $j$ that reduces $b_{j}$ is rewarded with additional investment. Such search is, however, not time consistent. As a result, competitive pressure is limited for case $(i)$ and vanishes completely for case $(i i)$.

In case $(i i)$ the tax burdens are equal to the tax burdens in autarchy. This result closely corresponds with the original result in Diamond (1971) and the recent result on additive two-component prices by Harrington and Leahey (2007).

The more important result is for case $(i)$. It shows that, despite the absence of search in the equilibrium, the costless observability of the tax rate exerts some partial competitive pressure on the effective tax burdens. As the tax base is bounded from above, the maximum possible effective tax burden can credibly be limited by the country if it chooses a tax rate that is so small that the product of this tax rate with the maximum possible (unobserved) tax base is smaller than the effective monopoly tax (i.e., if $\left.\tau_{0} \beta_{1}<T_{m}\right)$. For $\tau_{0}=0$ even the full race to the bottom occurs. Note also that the equilibrium in case $(i)$ has very low tax rates, combined with broad tax bases. This property is in line with the stylized facts on tax rate reductions and tax base broadening. 


\section{Conclusions}

Search cost for the effective tax burden is typically assumed away in tax competition analysis. However, if there is a cost to learning the true size of some of the determinants of the actual effective tax burden, this may limit the amount of competition pressure and may even support a tax competition equilibrium in which countries choose the effective tax burden that maximizes tax revenue, just as in the case with autarchy. The result is compatible with a large variety of combinations of tax rates and tax bases and may add to the existing explanations for why the trend towards lower statutory tax rates occurred in parallel with the increase in international openness in recent decades, and why it was complemented with a broadening of the corporate tax base.

\section{References}

[1] Arbatskaya, M., 2007, Ordered search, RAND Journal of Economics, $38(1), 119-126$.

[2] Baye, M.R., and J. Morgan, 2001, Information gatekeepers on the Internet and the competitiveness of homogeneous product markets, American Economic Review, 91(3), 454-474.

[3] Burdett, K., and K.L. Judd, 1983, Equilibrium price dispersion, Econometrica, 51(4), 955-969.

[4] De Mooij, R.A., and G. Nicodème, 2008, How corporate tax competition reduces personal tax revenue, CESifo DICE Report 1/2008, 27-31.

[5] Devereux, M.P., R. Griffith, and A. Klemm, 2002, Corporate income tax reforms and international tax competition, Economic Policy, 35, 451-488.

[6] Devereux, M.P., B. Lockwood, and M. Redoano, 2008, Do countries compete over corporate tax rates?, Journal of Public Economics, 92(56), 2008, 1210-1235.

[7] Diamond, P.A., 1971, A model of price adjustment, Journal of Economic Theory, 3(2), 156-168. 
[8] European Commission, 2001, Communication from the Commission to the Council, the European Parliament and the Economic and Social Committee, Towards an Internal Market without Tax Obstacles, A Strategy for Providing Companies with a Consolidated Corporate Tax Base for their EU-wide Activities, COM (2001), 582 Final, Brussels.

[9] Fuest, C., 1995, Interjurisdictional competition and public expenditure: is tax coordination counterproductive?, FinanzArchiv N.F., 52(3-4), 478-496.

[10] Fuest, C., B. Huber and J. Mintz, 2005, Capital mobility and tax competition, a survey, Foundations and Trends in Microeconomics, 1(1), $1-62$.

[11] Harrington, J.E. Jr., 2001, Comment on: "Reducing buyer search costs: implications for electronic market places", Management Science, 47(12), $1727-1732$.

[12] Harrington, J.E. Jr., and M.F. Leahey, 2007, Equilibrium pricing in a (partial) search market: The shopbot paradox, Economics Letters, 94(1), 111-117.

[13] Ireland, N.J., 2007, Posting multiple prices to reduce the effectiveness of consumer price search, Journal of Industrial Economics, 55(2), 235-263.

[14] McAfee, R.P., 1995, Multiproduct equilibrium price dispersion, Journal of Economic Theory, 67(1), 83-105.

[15] Sørensen, P.B., 2007, Can capital income taxes survive? And should they? CESifo Economic Studies, 53 (2), 172-228. 